\title{
Viruses, bacteria and Hallmarks of Cancer. Self-sufficiency in growth signals
}

\author{
Valentin Mitin \\ Institute of Genetics, Physiology and Protection of Plants. Moldova Republic of \\ Correspondence to: valentin_mitin@hotmail.com
}

\begin{abstract}
In 2000, Robert Weinberg and Douglas Hanahan proposed the 6 Hallmarks of Cancer, which are found in most if not all cancers. This article describes how 11 viruses and 8 bacteria may stimulate the development of the first hallmark, self-sufficiency in growth signals. For this, viruses and bacteria either stimulate the synthesis of growth factors in the cell, or activate growth factor receptors, or regulate the expression of a gene involved in the transduction of a signal of cell division initiation from growth factor receptor.
\end{abstract}

\section{Keywords}

virus - bacteria- Hallmarks of Cancer

\section{Background}

In 2000 Robert Weinberg and Douglas Hanahan published the paper "The Hallmarks of Cancer"[1]. In this paper the authors suggest that most if not all cancers have acquired the same set of functional capabilities during their development, albeit through various mechanistic strategies. This set of functional capabilities was called The Hallmarks of Cancer, which consist of 6 hallmarks: self-sufficiency in growth signals, insensitivity to growth-inhibitory (antigrowth) signals, evasion of programmed cell death (apoptosis), limitless replicative potential, sustained angiogenesis, and tissue invasion and metastasis. By this moment, this paper is cited for more than 28 thousand times. It is one of the most highly cited papers in the field of oncology. This can mean that many oncologists agree about the existence of a set of functional capabilities during cancer incidence and development.

At present it is believed that only about $15-20 \%$ of all cases of cancer can be caused by viruses and bacteria. We have previously described $[2,3]$ why and how viruses and bacteria can stimulate cancer development. It seems logical to consider if viruses and bacteria can favor the development of "The Hallmarks of Cancer" and if yes, how they do it. In the present paper the influence of viruses and bacteria (hereafter bacteria will mean intracellular bacteria) on the incidence of the first trait - self-sufficiency in growth signals.

\section{Main text}

When considering how viruses and bacteria can stimulate self-sufficiency in growth signals, we base on the assumption that viruses and intracellular bacteria are the beneficiaries of a continuous division of host cells, namely:

- $\quad$ First, S-phase of cell division is the phase when the synthesis of cellular DNA takes place and which is also the perfect time for reproduction of viruses and intracellular bacteria. During this time the cell environment is rich in nutrients necessary for reproduction of viruses and bacteria. That is why viruses and bacteria will aim for the cell spending as much time as possible in the S-phase of cell division.

- $\quad$ Second, cell division means expansion of life space for intracellular 
bacteria and viruses. This way of expansion does not require the release of viruses and bacteria from the cell, and does not jeopardize them with immune system attack.

Unlimited division of the host cells means unlimited expansion of the living space and possibility for unlimited multiplication of viral and bacterial particles.

To initiate cell division, viruses and bacteria must be able to affect the Activating system

\section{Activating system}

A cell found in $\mathrm{G} 0$ phase, can be forced out of the $\mathrm{G} 0$ phase by the external stimulating (mitogenic) influences, e.g. the effect of growth factors on the cell (growth factors mean any factors - growth factors, growth hormones, growth cytokines, Wnt etc., which effect on a corresponding receptor results in the appearance of Cyclin D and CDK4/6 in the cell). Growth factors through the receptors send the signal for division start to the cell through Ras, Jak/Stat and other signaling pathways, which, in turn, activate sufficient amount of genes for starting cell division. As a result of this activation, together with other gene products, Cyclins D and CDK4/6 proteins appear in the cell. In short, for further discussion it is necessary to understand, that the outcome of the stimulation of activating system is the appearance of Cyclins D and CDK4/6 in the cell. It is the occurrence of Cyclins D and CDK4/6 that triggers cell division (Figure 1).

\section{Cell division stimulation}

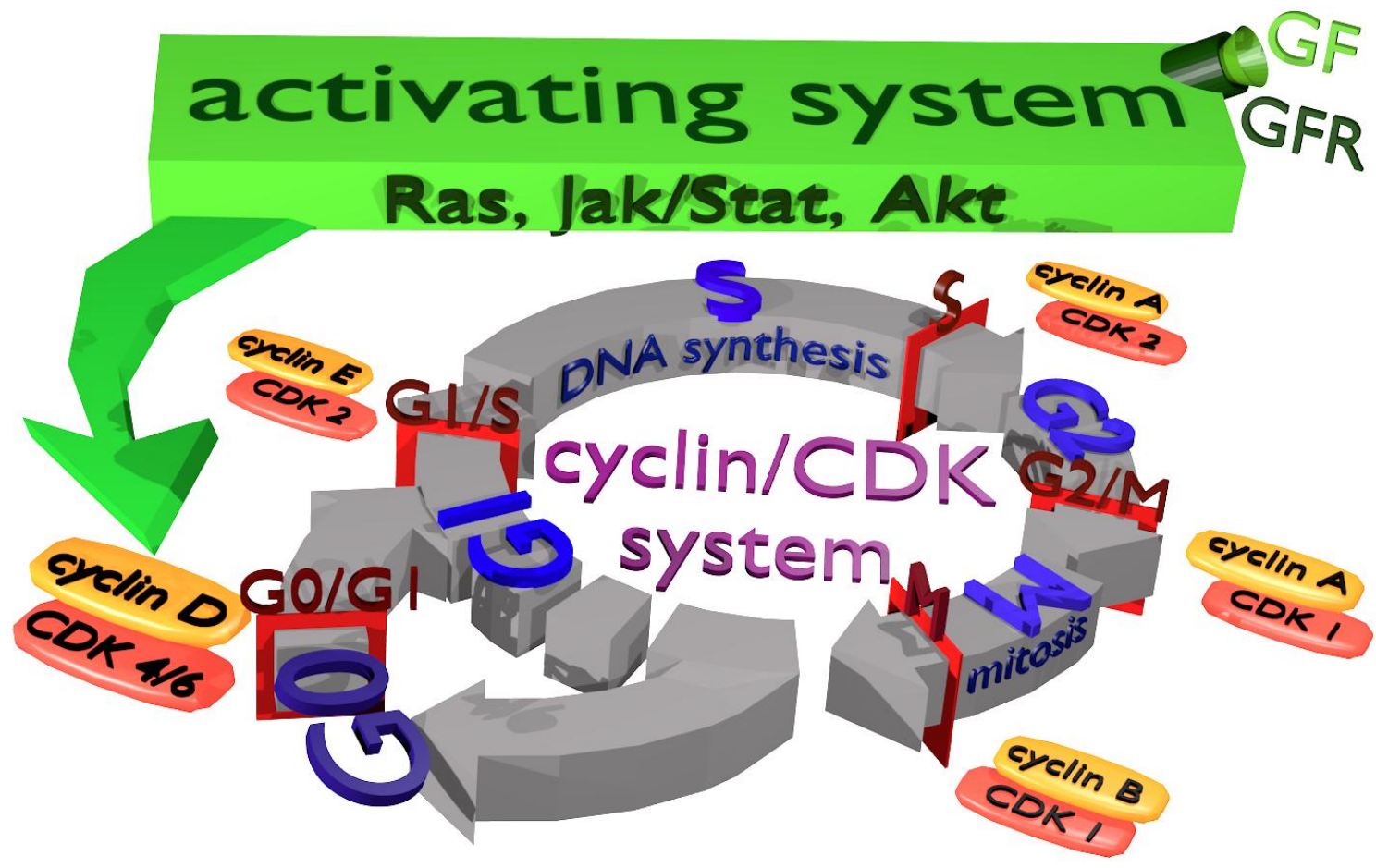

Figure 1. Cell division stimulation. The action of growth factors (GF) on a corresponding receptor (GFR) results in the appearance of Cyclin D and CDK4/6. Cyclin D and CDK4/6 complex initiates the process of cell division, which consists in sequential transitions to the cell division phases (G0-G1-S-G2-M). 


\section{Stimulation of activating system}

For a cell to enter $\mathrm{S}$ phase (phase of cellular DNA synthesis) viruses and bacteria must be capable of stimulating activating system. Theoretically, viruses can affect any of the genes involved in the transmission of the signal of activation (Ras, Raf, Myc etc) downstream the growth factor receptors until cyclins $\mathrm{D}$ и $\mathrm{CDK} 4 / 6$ proteins appear in the cell.

However, the best would be to affect a growth factor or a growth factor receptor. This case is similar to the normal stimulation of cell division, and it results in the suppression of the function of the genes of controlling system and suppression of apoptosis. In general, the ideal case of cell division initiation for viruses and bacteria is the case when a virus or bacteria can activate the synthesis of both growth factor and its receptor. In this case the receptor will be embedded into the cell membrane, and the synthesized growth factor, binding to its receptor, will stimulate cell division. Probably, using this last case, the virus can trigger division of any cell, no matter which growth factor used to control the division of this cell earlier (in this case the direction of cell differentiation can be changed). During stimulation of growth factor synthesis or stimulation of growth factor receptor, the controlling system is less likely to "suspect" a failure in the system function or external (viral or bacterial) interference.

Tables 1 and 2 summarize the information, how different viruses and bacteria can stimulate and maintain cell proliferation.

Table 1. Sustaining proliferative signaling in the cell by viruses.

\begin{tabular}{|c|c|c|c|c|}
\hline Virus & $\begin{array}{l}\text { Virus } \\
\text { gene }\end{array}$ & Impact on the cell & $\begin{array}{l}\text { Human } \\
\text { gene }\end{array}$ & $\begin{array}{l}\text { Proliferation, as a } \\
\text { consequence of the } \\
\text { impact on the cell }\end{array}$ \\
\hline \multirow[t]{2}{*}{ adenovirus } & $\begin{array}{l}\text { E4- } \\
\text { ORF1 }\end{array}$ & $\begin{array}{l}\text { Adenovirus E4-ORF1 } \\
\text { dysregulates EGFR and } \\
\text { IGFR to mediate } \\
\text { constitutive Myc } \\
\text { expression [4] }\end{array}$ & $\begin{array}{l}\text { EGFR, } \\
\text { IGFR }\end{array}$ & $\begin{array}{l}\text { EGF receptor is involved } \\
\text { in WNT3a-mediated } \\
\text { proliferation ...via ERK } \\
\text { pathway activation [5] }\end{array}$ \\
\hline & E1A & $\begin{array}{l}\text { Adenoviral E1A function } \\
\text { through Myc [6] }\end{array}$ & Myc & $\begin{array}{l}\text { c-Myc recruits P-TEFb } \\
\text { for ... cellular } \\
\text { proliferation ... 77] }\end{array}$ \\
\hline \multirow{4}{*}{$\begin{array}{l}\text { hepatitis B } \\
\text { virus }\end{array}$} & HBx & $\begin{array}{l}\text { Trans-activation of } \\
\text { epidermal growth factor } \\
\text { receptor gene by the } \\
\text { hepatitis B virus X-gene } \\
\text { product [8] }\end{array}$ & EGFR & $\begin{array}{l}\text { Role of epidermal growth } \\
\text { factor receptor ... in } \\
\text { autonomous proliferation } \\
\text { of ... human breast } \\
\text { cancer cells [9] }\end{array}$ \\
\hline & HBx & $\begin{array}{l}\text { The human hepatitis B } \\
\text { virus transactivator X gene } \\
\text { product regulates ... } \\
\text { transcription of an insulin- } \\
\text { like growth factor II ... } \\
\text { [10] }\end{array}$ & IGFR II & $\begin{array}{l}\text { Insulin-like growth factor } \\
\text { II stimulates cell } \\
\text { proliferation through the } \\
\text { insulin receptor [11] }\end{array}$ \\
\hline & HBx & $\begin{array}{l}\text { Hepatitis B virus X protein } \\
\text { is essential for the } \\
\text { activation of Wnt/beta- } \\
\text { catenin signaling ... [12] }\end{array}$ & $\begin{array}{l}\text { Wnt/beta } \\
\text {-catenin }\end{array}$ & $\begin{array}{l}\text { Wnt signaling promotes } \\
\text { proliferation ... [13] }\end{array}$ \\
\hline & $\mathrm{HBx}$ & Activation of Src family & Src & Src family kinases are \\
\hline
\end{tabular}




\begin{tabular}{|c|c|c|c|c|}
\hline & & $\begin{array}{l}\text { kinases by hepatitis B } \\
\text { virus HBx protein [14] }\end{array}$ & & $\begin{array}{l}\text { required for... induction } \\
\text { of cell proliferation [15] }\end{array}$ \\
\hline \multirow{4}{*}{$\begin{array}{l}\text { Hepatitis } \mathrm{C} \\
\text { virus }\end{array}$} & & $\begin{array}{l}\text { Hepatitis } C \text { virus induces } \\
\text { epidermal growth factor } \\
\text { receptor activation... [16] }\end{array}$ & EGFR & $\begin{array}{l}\text { Epidermal growth factor } \\
\text { receptor-directed } \\
\text { enterocyte } \\
\text { proliferation... [17] }\end{array}$ \\
\hline & core & $\begin{array}{l}\text { Hepatitis C virus core } \\
\text { protein transactivates } \\
\text { insulin-like growth factor } \\
\text { II gene [18] }\end{array}$ & IGF II & $\begin{array}{l}\text { Insulin-like growth } \\
\text { factor-1 and -2 stimulate } \\
\text { osteoprogenitor } \\
\text { proliferation [19] }\end{array}$ \\
\hline & core & $\begin{array}{l}\text { Hepatitis C virus core } \\
\text { protein upregulates } \\
\text { transforming growth } \\
\text { factor-beta } 1 \text { transcription } \\
\text { [20] }\end{array}$ & $\begin{array}{l}\text { TGF beta } \\
1\end{array}$ & $\begin{array}{l}\text { Transforming growth } \\
\text { factor beta } 1 \text { induces } \\
\text { proliferation in colon } \\
\text { carcinoma cells... [21] }\end{array}$ \\
\hline & core & $\begin{array}{l}\text { Hepatitis } C \text { virus core } \\
\text { protein activates } W n t / \beta \text { - } \\
\text { catenin signaling... [22] }\end{array}$ & $\begin{array}{l}\text { Wnt } / \beta- \\
\text { catenin }\end{array}$ & $\begin{array}{l}\text { Wnt signaling promotes } \\
\text { androgen-independent } \\
\text { prostate cancer cell } \\
\text { proliferation... [23] }\end{array}$ \\
\hline $\begin{array}{l}\text { herpes simplex } \\
\text { virus }\end{array}$ & & $\begin{array}{l}\text { Induction of transforming } \\
\text { growth factor-beta } 1 \\
\text { production in human cells } \\
\text { by herpes simplex virus } \\
{[24]}\end{array}$ & TGF- $\beta 1$ & $\begin{array}{l}\text { Transforming growth } \\
\text { factor-beta } 1 \\
\text { differentially regulates } \\
\text { proliferation... [25] }\end{array}$ \\
\hline \multirow{3}{*}{ HIV-1 } & Tat & $\begin{array}{l}\text { HIV-1 Tat-mediated } \\
\text { induction of platelet- } \\
\text { derived growth factor in } \\
\text { astrocytes... [26] }\end{array}$ & PDGF & $\begin{array}{l}\text { Platelet-derived growth- } \\
\text { factor requirements for in } \\
\text { vitro proliferation of } \\
\text { normal and malignant } \\
\text { mesenchymal cells [27] }\end{array}$ \\
\hline & gp160 & $\begin{array}{l}\text { HIV-1 gp160 induces } \\
\text { transforming growth } \\
\text { factor-beta production in } \\
\text { human PBMC [28] }\end{array}$ & $\begin{array}{l}\text { TGF- } \\
\text { beta }\end{array}$ & $\begin{array}{l}\text { Transforming growth } \\
\text { factor-beta regulates } \\
\text { basal transcriptional } \\
\text { regulatory machinery to } \\
\text { control cell } \\
\text { proliferation... [29] }\end{array}$ \\
\hline & gp120 & $\begin{array}{l}\text { HIV-1 gp120 Upregulates } \\
\text { Brain-Derived } \\
\text { Neurotrophic Factor } \\
\text { (BDNF) Expression } \\
\text {...[30] }\end{array}$ & BDNF & $\begin{array}{l}\text { Brain-derived } \\
\text { neurotrophic factor } \\
\text { stimulates proliferation } \\
\text { and differentiation of } \\
\text { neural stem cells... [31] }\end{array}$ \\
\hline \multirow{3}{*}{$\begin{array}{l}\text { Epstein-Barr } \\
\text { virus }\end{array}$} & LMP 1 & $\begin{array}{l}\text { Epstein-Barr virus latent } \\
\text { membrane protein } 1 \\
\text { induces expression of the } \\
\text { epidermal growth factor } \\
\text { receptor [32] }\end{array}$ & EGFR & $\begin{array}{l}\text { The epidermal growth } \\
\text { factor receptor is } \\
\text { required to maintain the } \\
\text { proliferative } \\
\text { population... [33] }\end{array}$ \\
\hline & LMP 1 & $\begin{array}{l}\text { Epstein-barr virus latent } \\
\text { membrane protein } 1 \\
\text { induces and causes release } \\
\text { of fibroblast growth } \\
\text { factor-2 [34] }\end{array}$ & FGF-2 & $\begin{array}{l}\text { Basic fibroblast growth } \\
\text { factor stimulates the } \\
\text { proliferation of human } \\
\text { dermal fibroblasts... [35] }\end{array}$ \\
\hline & $\begin{array}{l}\text { small } \\
\text { RNA }\end{array}$ & $\begin{array}{l}\text { Epstein-Barr virus- } \\
\text { encoded small RNA }\end{array}$ & IGF-1 & $\begin{array}{l}\text { Insulin-like growth factor } \\
1 \text { and oestradiol promote }\end{array}$ \\
\hline
\end{tabular}




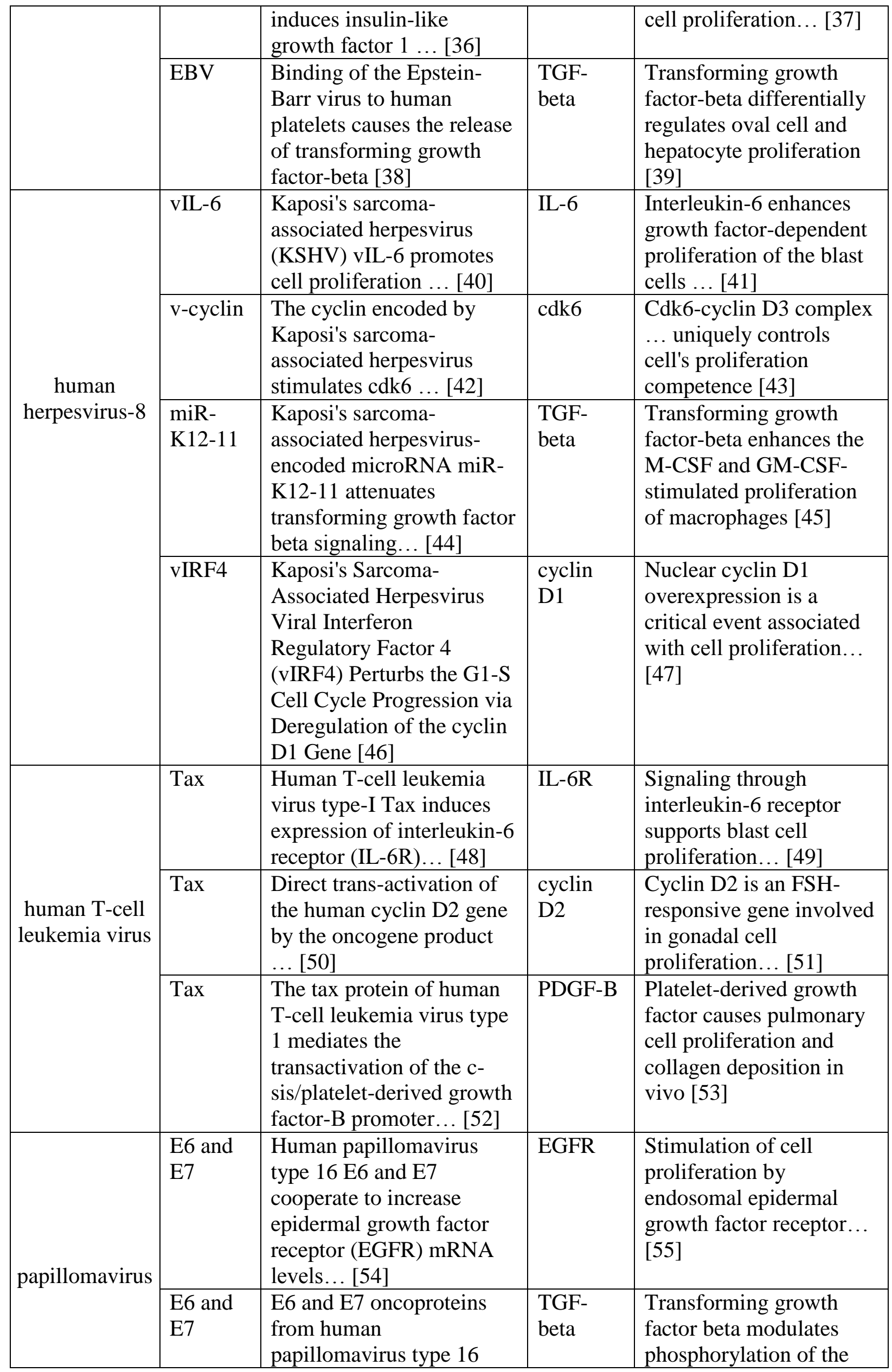




\begin{tabular}{|c|c|c|c|c|}
\hline & & $\begin{array}{l}\text { induce activation of } \\
\text { human transforming } \\
\text { growth factor beta1 } \\
\text { promoter... [56] }\end{array}$ & & $\begin{array}{l}\text { epidermal growth factor } \\
\text { receptor and proliferation } \\
\text { of A431 cells [57] }\end{array}$ \\
\hline \multirow{4}{*}{ polyomavirus } & $\begin{array}{l}\text { large } \mathrm{T} \\
\text { antigen }\end{array}$ & $\begin{array}{l}\text { The SV40 large T antigen- } \\
\text { p53 complexes bind and } \\
\text { activate the insulin-like } \\
\text { growth factor-I promoter } \\
\ldots \text {.. [58] }\end{array}$ & ILGF-1 & $\begin{array}{l}\text { Insulin-like growth } \\
\text { factor-I promotes } \\
\text { proliferation and } \\
\text { migration of cavernous } \\
\text { smooth muscle cells [59] }\end{array}$ \\
\hline & $\begin{array}{l}\text { Middle- } \\
\mathrm{T} \\
\text { antigen }\end{array}$ & $\begin{array}{l}\text { Middle-T associates with } \\
\text { and thereby activates } \\
\text { p60c-src, a cellular } \\
\text { tyrosine kinase } \\
\text { homologous to the } \\
\text { oncogene product of Rous } \\
\text { sarcoma virus [60] }\end{array}$ & SRC & $\begin{array}{l}\text { Src stimulates insulin- } \\
\text { like growth factor I (IGF- } \\
\text { I)-dependent cell } \\
\text { proliferation ... [61] }\end{array}$ \\
\hline & $\begin{array}{l}\text { Middle- } \\
\mathrm{T} \\
\text { antigen }\end{array}$ & $\begin{array}{l}\text { Middle T .... interacts } \\
\text { with a number of the } \\
\text { proteins used by tyrosine } \\
\text { kinase associated receptors } \\
\text { to stimulate mitogenesis... } \\
{[62]}\end{array}$ & $\begin{array}{l}\text { tyrosine } \\
\text { kinase }\end{array}$ & $\begin{array}{l}\text { Simultaneous targeting } \\
\text { of Src kinase and } \\
\text { receptor tyrosine kinase } \\
\text { results in synergistic } \\
\text { inhibition of renal cell } \\
\text { carcinoma proliferation } \\
\text { and migration [63] }\end{array}$ \\
\hline & $\begin{array}{l}\text { small } \mathrm{T} \\
\text { antigen }\end{array}$ & $\begin{array}{l}\text { Induction of cyclin D1 by } \\
\text { simian virus } 40 \text { small } \\
\text { tumor antigen [64] }\end{array}$ & $\begin{array}{l}\text { cyclin } \\
\text { D1 }\end{array}$ & $\begin{array}{l}\text { A cyclin D1/microRNA } \\
17 / 20 \text { regulatory } \\
\text { feedback loop in control } \\
\text { of breast cancer cell } \\
\text { proliferation [65] }\end{array}$ \\
\hline \multirow[t]{2}{*}{ poxvirus } & A49 & $\begin{array}{l}\text { Vaccinia virus protein A49 } \\
\text { activates Wnt signalling } \\
\text { by targetting the E3 ligase } \\
\beta-\operatorname{TrCP}[66]\end{array}$ & Wnt & $\begin{array}{l}\text { Wnt3a is critical for } \\
\text { endothelial progenitor } \\
\text { cell-mediated neural } \\
\text { stem cell proliferation } \\
\text { and differentiation [67] }\end{array}$ \\
\hline & A52 & $\begin{array}{l}\text { Poxviral protein A52 } \\
\text { stimulates p38 mitogen- } \\
\text { activated protein kinase } \\
\text { (MAPK) activation...[68] }\end{array}$ & MAPK & $\begin{array}{l}\text { A p38 MAPK-MEF2C } \\
\text { pathway regulates B-cell } \\
\text { proliferation [69] }\end{array}$ \\
\hline
\end{tabular}

Table 2. Sustaining proliferative signaling in the cell by bacteria.

\begin{tabular}{|c|l|c|l|}
\hline Bacteria & \multicolumn{1}{|c|}{ Impact on the cell } & $\begin{array}{c}\text { Human } \\
\text { gene }\end{array}$ & $\begin{array}{l}\text { Proliferation, as a consequence of } \\
\text { the impact on the cell }\end{array}$ \\
\hline \multirow{3}{*}{ Chlamydia } & $\begin{array}{l}\text {. . Chlamydia trachomatis } \\
\text { increases the phosphorylation } \\
\text { of EGFR ... [70] }\end{array}$ & EGFR & $\begin{array}{l}\text { Epidermal growth factor receptor } \\
\text { (EGFR) signaling promotes } \\
\text { proliferation... [71] }\end{array}$ \\
\cline { 2 - 4 } & $\begin{array}{l}\text {.. C. pneumoniae activates } \\
\text { endothelial cells to produce } \\
\text { bFGF .. [72] }\end{array}$ & bFGF & $\begin{array}{l}\text { Basic fibroblast growth factor } \\
\text { induces cell migration and } \\
\text { proliferation .. [73] }\end{array}$ \\
\hline Escherichia coli & $\begin{array}{l}\text { Enteropathogenic Escherichia } \\
\text { coli-induced epidermal growth }\end{array}$ & EGFR & $\begin{array}{l}\text { Epidermal growth factor receptor } \\
\text { transactivation is implicated in IL-6- }\end{array}$ \\
\hline
\end{tabular}




\begin{tabular}{|c|c|c|c|}
\hline & $\begin{array}{l}\text { factor receptor activation... } \\
{[74]}\end{array}$ & & $\begin{array}{l}\text { induced proliferation and ERK } 1 / 2 \ldots \\
{[75]}\end{array}$ \\
\hline \multirow[b]{2}{*}{$\begin{array}{c}\text { Helicobacter } \\
\text { pylori }\end{array}$} & $\begin{array}{l}\text { Activation of beta-catenin by } \\
\text { carcinogenic Helicobacter } \\
\text { pylori [76] }\end{array}$ & $\begin{array}{l}\text { beta- } \\
\text { catenin }\end{array}$ & $\begin{array}{l}\beta \text {-Catenin and p120 mediate PPAR } \delta \text { - } \\
\text { dependent proliferation induced by } \\
\text { Helicobacter pylori ... [77] }\end{array}$ \\
\hline & $\begin{array}{l}\text { Helicobacter pylori activate } \\
\text { epidermal growth factor } \\
\text { receptor... [78] }\end{array}$ & EGFR & $\begin{array}{l}\text { Epidermal growth factor receptor } \\
\text { mediates increased cell } \\
\text { proliferation... [79] }\end{array}$ \\
\hline $\begin{array}{l}\text { Mycobacterium } \\
\text { leprae }\end{array}$ & $\begin{array}{l}\text { Mycobacterium leprae induces } \\
\text { insulin-like growth factor... } \\
{[80]}\end{array}$ & ILGF & $\begin{array}{l}\text { Insulin-like growth factor induces the } \\
\text { survival and proliferation of } \\
\text { myeloma cells... [81] }\end{array}$ \\
\hline \multirow[b]{2}{*}{$\begin{array}{l}\text { Mycobacterium } \\
\text { tuberculosis }\end{array}$} & $\begin{array}{l}\text { Activation of the Wnt pathway } \\
\text { by Mycobacterium } \\
\text { tuberculosis... [82] }\end{array}$ & Wnt & $\begin{array}{l}\text { Notch and Wnt signals cooperatively } \\
\text { control cell proliferation and } \\
\text { tumorigenesis in the intestine [83] }\end{array}$ \\
\hline & $\begin{array}{l}\text { Induction of transforming } \\
\text { growth factor beta } 1 \text { by purified } \\
\text { protein derivative of } \\
\text { Mycobacterium tuberculosis } \\
{[84]}\end{array}$ & $\begin{array}{l}\text { TGF- } \\
\text { beta } 1\end{array}$ & $\begin{array}{l}\text { Transforming growth factor beta } \\
\text { activation of p44mapk in } \\
\text { proliferating cultures of epithelial } \\
\text { cells [85] }\end{array}$ \\
\hline Mycoplasma & $\begin{array}{l}\text { Mycoplasma fermentans- } \\
\text { derived high-molecular-weight } \\
\text { material induces interleukin-6 } \\
\text { release... [86] }\end{array}$ & IL-6 & $\begin{array}{l}\text { Intracellular interleukin } 6 \text { mediates } \\
\text { platelet-derived growth factor- } \\
\text { induced proliferation of } \\
\text { nontransformed cells [87] }\end{array}$ \\
\hline Staphylococcus & $\begin{array}{l}\text { Pore-forming Staphylococcus } \\
\text { aureus alpha-toxin triggers } \\
\text { epidermal growth factor } \\
\text { receptor-dependent } \\
\text { proliferation[88] }\end{array}$ & EGFR & $\begin{array}{l}\text { Epidermal growth factor induces } \\
\text { bladder cancer cell proliferation } \\
\text { through activation of the androgen } \\
\text { receptor [89] }\end{array}$ \\
\hline Toxoplasma & $\begin{array}{l}\text { Toxoplasma gondii induces } \\
\text { granulocyte colony-stimulating } \\
\text { factor and granulocyte- } \\
\text { macrophage colony-stimulating } \\
\text { factor secretion [90] }\end{array}$ & $\begin{array}{l}\text { G-CSF, } \\
\text { GM- } \\
\text { CSF }\end{array}$ & $\begin{array}{l}\text { Effects of granulocyte-colony- } \\
\text { stimulating factor and } \\
\text { granulocyte/macrophage-colony- } \\
\text { stimulating factor administration on } \\
\text { T cell proliferation...[91] }\end{array}$ \\
\hline
\end{tabular}

\section{Conclusions}

The above data indicate that the capability of viruses and bacteria of sustaining selfsufficiency in growth signals is rather common. What can this capability of viruses and bacteria indicate?

As viral particles reproduce, high frequency of mutations in genomes of viruses will result in the increased divergence of virus genomes, forming a cloud of quasispecies. The occurrence of such a cloud of mutant viruses can favor rapid adaptation of the virus to changing environment and improve its resiliency. On the other hand, considering that during millions of years of evolution of viral genomes, the nucleotide sequences for each gene of a virus were optimized, one can expect that the mutations appearing during replication of viruses will reduce the efficacy of the mutated genes and reduce competitiveness of viral particles. This may not be crucial as long as the viruses are inside the same cell, since the "correct" versions of the genes co-reside in the same cell. If the viruses are released from the cell, the viral particles with the minimal changes to the genomes will have the highest competiveness. They will force the 
mutated viral particles out of further replication. Besides, due to continuing mutagenesis, the survived viral particles will tend to have the ideal nucleotide sequence. Natural selection allows preserving the optimal nucleotide sequence of viral genome even during extended (long-term) reproduction in different habitats. The similarity of sequenced regions of genomes of viruses of the same species supports such assumption. Sequenced sequences only slightly vary from some "consensus" sequence. This variation is smaller in the genes crucial for the virus, for example, polymerase-coding genes, and is higher in the genes, not essential for the survival of the virus (for example, genes of envelope), or even favoring the survival of the virus.

However, this may mean that viruses, especially viruses with relatively small genome, are unlikely to retain in their genome unessential sequences which are not important for virus survival. Therefore, the presence in the viral genome of the genes, capable of keeping selfsufficiency in growth signals in the cell can mean that viruses need such genes, that these genes offer additional advantages for species maintenance to the viruses. Considering that along with the viruses, a number of bacteria is capable of inducing self-sufficiency in growth signals (see table 1,2), such ability apparently gives them significant advantages. Since growth signals initiate cell division, it can mean that viruses and bacteria are interested in cell division and that they benefit from this process.

\section{Acknowledgements}

The author thank Irina Mitina for writing assistance

\section{References}

1. Hanahan D, Weinberg RA: The hallmarks of cancer. Cell 2000, 100(1):57-70.

2. Mitin V: Cancer is a side effect of evolution of viruses and bacteria. Available from Nature Precedings <http://dx.doi.org/10.1038/npre.2011.63221> 2011.

3. Mitin V: Oncogenome Model of Cancer Development. Open Science Framework October 12 doi:10.17605/OSF.IO/QBPCN 2017.

4. Kong K, Kumar M, Taruishi M, Javier RT: Adenovirus E4-ORF1 Dysregulates Epidermal Growth Factor and Insulin/Insulin-Like Growth Factor Receptors To Mediate Constitutive Myc Expression. J Virol 2015, 89(21):10774-10785.

5. Kim SE, Choi KY: EGF receptor is involved in WNT3a-mediated proliferation and motility of NIH3T3 cells via ERK pathway activation. Cell Signal 2007, 19(7):15541564.

6. Chakraborty AA, Tansey WP: Adenoviral E1A function through Myc. Cancer Res 2009, 69(1):6-9.

7. Kanazawa S, Soucek L, Evan G, Okamoto T, Peterlin BM: c-Myc recruits P-TEFb for transcription, cellular proliferation and apoptosis. Oncogene 2003, 22(36):5707-5711.

8. Menzo S, Clementi M, Alfani E, Bagnarelli P, Iacovacci S, Manzin A, Dandri M, Natoli G, Levrero M, Carloni G: Trans-activation of epidermal growth factor receptor gene by the hepatitis B virus X-gene product. Virology 1993, 196(2):878-882.

9. Sartor CI, Dziubinski ML, Yu CL, Jove R, Ethier SP: Role of epidermal growth factor receptor and STAT-3 activation in autonomous proliferation of SUM-102PT human breast cancer cells. Cancer Res 1997, 57(5):978-987.

10. Lee YI, Lee S, Lee Y, Bong YS, Hyun SW, Yoo YD, Kim SJ, Kim YW, Poo HR: The human hepatitis $B$ virus transactivator $X$ gene product regulates $S p 1$ mediated transcription of an insulin-like growth factor II promoter 4. Oncogene 1998, 16(18):2367-2380. 
11. Morrione A, Valentinis B, Xu SQ, Yumet G, Louvi A, Efstratiadis A, Baserga R: Insulin-like growth factor II stimulates cell proliferation through the insulin receptor. Proc Natl Acad Sci U S A 1997, 94(8):3777-3782.

12. Cha MY, Kim CM, Park YM, Ryu WS: Hepatitis B virus X protein is essential for the activation of Wnt/beta-catenin signaling in hepatoma cells. Hepatology 2004, 39(6):1683-1693.

13. Golestaneh N, Beauchamp E, Fallen S, Kokkinaki M, Uren A, Dym M: Wnt signaling promotes proliferation and stemness regulation of spermatogonial stem/progenitor cells. Reproduction 2009, 138(1):151-162.

14. Klein NP, Schneider RJ: Activation of Src family kinases by hepatitis B virus HBx protein and coupled signaling to Ras. Mol Cell Biol 1997, 17(11):6427-6436.

15. Fresno Vara JA, Cáceres MA, Silva A, Martín-Pérez J: Src family kinases are required for prolactin induction of cell proliferation. Mol Biol Cell 2001, 12(7):2171-2183.

16. Diao J, Pantua H, Ngu H, Komuves L, Diehl L, Schaefer G, Kapadia SB: Hepatitis C virus induces epidermal growth factor receptor activation via CD81 binding for viral internalization and entry. $J$ Virol 2012, 86(20):10935-10949.

17. Taylor JA, Bernabe KQ, Guo J, Warner BW: Epidermal growth factor receptordirected enterocyte proliferation does not induce Wnt pathway transcription. $J$ Pediatr Surg 2007, 42(6):981-986.

18. Lee S, Park U, Lee YI: Hepatitis $\mathbf{C}$ virus core protein transactivates insulin-like growth factor II gene transcription through acting concurrently on Egr1 and Sp1 sites. Virology 2001, 283(2):167-177.

19. Jia D, Heersche JN: Insulin-like growth factor-1 and -2 stimulate osteoprogenitor proliferation and differentiation and adipocyte formation in cell populations derived from adult rat bone. Bone 2000, 27(6):785-794.

20. Taniguchi H, Kato N, Otsuka M, Goto T, Yoshida H, Shiratori Y, Omata M: Hepatitis C virus core protein upregulates transforming growth factor-beta 1 transcription. $J$ Med Virol 2004, 72(1):52-59.

21. Yan Z, Kim GY, Deng X, Friedman E: Transforming growth factor beta 1 induces proliferation in colon carcinoma cells by Ras-dependent, smad-independent downregulation of p21cip1. J Biol Chem 2002, 277(12):9870-9879.

22. Liu J, Wang Z, Tang J, Tang R, Shan X, Zhang W, Chen Q, Zhou F, Chen K, Huang A et al: Hepatitis $\mathrm{C}$ virus core protein activates $\mathrm{Wnt} / \boldsymbol{\beta}$-catenin signaling through multiple regulation of upstream molecules in the SMMC-7721 cell line. Arch Virol 2011, 156(6):1013-1023.

23. Seo WI, Park S, Gwak J, Ju BG, Chung JI, Kang PM, Oh S: Wnt signaling promotes androgen-independent prostate cancer cell proliferation through up-regulation of the hippo pathway effector YAP. Biochem Biophys Res Commun 2017, 486(4):10341039.

24. Méndez-Samperio P, Hernandez M, Ayala HE: Induction of transforming growth factor-beta 1 production in human cells by herpes simplex virus. J Interferon Cytokine Res 2000, 20(3):273-280.

25. Rogers SL, Cutts JL, Gegick PJ, McGuire PG, Rosenberger C, Krisinski S: Transforming growth factor-beta 1 differentially regulates proliferation, morphology, and extracellular matrix expression by three neural crest-derived neuroblastoma cell lines. Exp Cell Res 1994, 211(2):252-262.

26. Bethel-Brown C, Yao H, Callen S, Lee YH, Dash PK, Kumar A, Buch S: HIV-1 Tatmediated induction of platelet-derived growth factor in astrocytes: role of early growth response gene 1. J Immunol 2011, 186(7):4119-4129.

27. Currie GA: Platelet-derived growth-factor requirements for in vitro proliferation of normal and malignant mesenchymal cells. Br J Cancer 1981, 43(3):335-343. 
28. Hu R, Oyaizu N, Than S, Kalyanaraman VS, Wang XP, Pahwa S: HIV-1 gp160 induces transforming growth factor-beta production in human PBMC. Clin Immunol Immunopathol 1996, 80(3 Pt 1):283-289.

29. Iwata J, Hosokawa R, Sanchez-Lara PA, Urata M, Slavkin H, Chai Y: Transforming growth factor-beta regulates basal transcriptional regulatory machinery to control cell proliferation and differentiation in cranial neural crest-derived osteoprogenitor cells. J Biol Chem 2010, 285(7):4975-4982.

30. Wang Y, Liao J, Tang SJ, Shu J, Zhang W: HIV-1 gp120 Upregulates Brain-Derived Neurotrophic Factor (BDNF) Expression in BV2 Cells via the Wnt/ $\beta$-Catenin Signaling Pathway. J Mol Neurosci 2017, 62(2):199-208.

31. Chen BY, Wang X, Wang ZY, Wang YZ, Chen LW, Luo ZJ: Brain-derived neurotrophic factor stimulates proliferation and differentiation of neural stem cells, possibly by triggering the Wnt/B-catenin signaling pathway. J Neurosci Res 2013, 91(1):30-41.

32. Kung CP, Raab-Traub N: Epstein-Barr virus latent membrane protein 1 induces expression of the epidermal growth factor receptor through effects on Bcl-3 and STAT3. $J$ Virol 2008, 82(11):5486-5493.

33. Hansen LA, Woodson RL, Holbus S, Strain K, Lo YC, Yuspa SH: The epidermal growth factor receptor is required to maintain the proliferative population in the basal compartment of epidermal tumors. Cancer Res 2000, 60(13):3328-3332.

34. Wakisaka N, Murono S, Yoshizaki T, Furukawa M, Pagano JS: Epstein-barr virus latent membrane protein 1 induces and causes release of fibroblast growth factor-2. Cancer Res 2002, 62(21):6337-6344.

35. Makino T, Jinnin M, Muchemwa FC, Fukushima S, Kogushi-Nishi H, Moriya C, Igata T, Fujisawa A, Johno T, Ihn H: Basic fibroblast growth factor stimulates the proliferation of human dermal fibroblasts via the ERK1/2 and JNK pathways. $\mathrm{Br} J$ Dermatol 2010, 162(4):717-723.

36. Iwakiri D, Sheen TS, Chen JY, Huang DP, Takada K: Epstein-Barr virus-encoded small RNA induces insulin-like growth factor 1 and supports growth of nasopharyngeal carcinoma-derived cell lines. Oncogene 2005, 24(10):1767-1773.

37. Dupont J, Le Roith D: Insulin-like growth factor $\mathbf{1}$ and oestradiol promote cell proliferation of MCF-7 breast cancer cells: new insights into their synergistic effects. Mol Pathol 2001, 54(3):149-154.

38. Ahmad A, Menezes J: Binding of the Epstein-Barr virus to human platelets causes the release of transforming growth factor-beta. J Immunol 1997, 159(8):3984-3988.

39. Nguyen LN, Furuya MH, Wolfraim LA, Nguyen AP, Holdren MS, Campbell JS, Knight $\mathrm{B}$, Yeoh GC, Fausto N, Parks WT: Transforming growth factor-beta differentially regulates oval cell and hepatocyte proliferation. Hepatology 2007, 45(1):31-41.

40. Wu J, Xu Y, Mo D, Huang P, Sun R, Huang L, Pan S, Xu J: Kaposi's sarcomaassociated herpesvirus (KSHV) vIL-6 promotes cell proliferation and migration by upregulating DNMT1 via STAT3 activation. PLoS One 2014, 9(3):e93478.

41. Hoang T, Haman A, Goncalves O, Wong GG, Clark SC: Interleukin-6 enhances growth factor-dependent proliferation of the blast cells of acute myeloblastic leukemia. Blood 1988, 72(2):823-826.

42. Godden-Kent D, Talbot SJ, Boshoff C, Chang Y, Moore P, Weiss RA, Mittnacht S: The cyclin encoded by Kaposi's sarcoma-associated herpesvirus stimulates cdk6 to phosphorylate the retinoblastoma protein and histone H1. J Virol 1997, 71(6):41934198.

43. Lin J, Jinno S, Okayama H: Cdk6-cyclin D3 complex evades inhibition by inhibitor proteins and uniquely controls cell's proliferation competence. Oncogene 2001, 20(16):2000-2009. 
44. Liu Y, Sun R, Lin X, Liang D, Deng Q, Lan K: Kaposi's sarcoma-associated herpesvirus-encoded microRNA miR-K12-11 attenuates transforming growth factor beta signaling through suppression of SMAD5. J Virol 2012, 86(3):1372-1381.

45. Celada A, Maki RA: Transforming growth factor-beta enhances the M-CSF and GM-CSF-stimulated proliferation of macrophages. J Immunol 1992, 148(4):11021105.

46. Lee HR, Mitra J, Lee S, Gao SJ, Oh TK, Kim MH, Ha T, Jung JU: Kaposi's SarcomaAssociated Herpesvirus Viral Interferon Regulatory Factor 4 (vIRF4) Perturbs the G1-S Cell Cycle Progression via Deregulation of the cyclin D1 Gene. J Virol 2016, 90(2):1139-1143.

47. Itoi T, Shinohara Y, Takeda K, Nakamura K, Takei K, Sanada J, Horibe T, Saito T, Kasuya K, Ebihara Y: Nuclear cyclin D1 overexpression is a critical event associated with cell proliferation and invasive growth in gallbladder carcinogenesis. $J$ Gastroenterol 2000, 35(2):142-149.

48. Horiuchi S, Yamamoto N, Dewan MZ, Takahashi Y, Yamashita A, Yoshida T, Nowell MA, Richards PJ, Jones SA: Human T-cell leukemia virus type-I Tax induces expression of interleukin-6 receptor (IL-6R): Shedding of soluble IL-6R and activation of STAT3 signaling. Int J Cancer 2006, 119(4):823-830.

49. Säily M, Koistinen P, Zheng A, Savolainen ER: Signaling through interleukin-6 receptor supports blast cell proliferation in acute myeloblastic leukemia. Eur $J$ Haematol 1998, 61(3):190-196.

50. Huang Y, Ohtani K, Iwanaga R, Matsumura Y, Nakamura M: Direct trans-activation of the human cyclin D2 gene by the oncogene product Tax of human T-cell leukemia virus type I. Oncogene 2001, 20(9):1094-1102.

51. Sicinski P, Donaher JL, Geng Y, Parker SB, Gardner H, Park MY, Robker RL, Richards JS, McGinnis LK, Biggers JD et al: Cyclin D2 is an FSH-responsive gene involved in gonadal cell proliferation and oncogenesis. Nature 1996, 384(6608):470-474.

52. Trejo SR, Fahl WE, Ratner L: The tax protein of human T-cell leukemia virus type 1 mediates the transactivation of the c-sis/platelet-derived growth factor-B promoter through interactions with the zinc finger transcription factors Sp1 and NGFIA/Egr-1. J Biol Chem 1997, 272(43):27411-27421.

53. Yi ES, Lee H, Yin S, Piguet P, Sarosi I, Kaufmann S, Tarpley J, Wang NS, Ulich TR: Platelet-derived growth factor causes pulmonary cell proliferation and collagen deposition in vivo. Am J Pathol 1996, 149(2):539-548.

54. Akerman GS, Tolleson WH, Brown KL, Zyzak LL, Mourateva E, Engin TS, Basaraba A, Coker AL, Creek KE, Pirisi L: Human papillomavirus type 16 E6 and E7 cooperate to increase epidermal growth factor receptor (EGFR) mRNA levels, overcoming mechanisms by which excessive EGFR signaling shortens the life span of normal human keratinocytes. Cancer Res 2001, 61(9):3837-3843.

55. Pennock S, Wang Z: Stimulation of cell proliferation by endosomal epidermal growth factor receptor as revealed through two distinct phases of signaling. Mol Cell Biol 2003, 23(16):5803-5815.

56. Peralta-Zaragoza O, Bermúdez-Morales V, Gutiérrez-Xicotencatl L, Alcocer-González J, Recillas-Targa F, Madrid-Marina V: E6 and E7 oncoproteins from human papillomavirus type 16 induce activation of human transforming growth factor beta1 promoter throughout Sp1 recognition sequence. Viral Immunol 2006, 19(3):468-480.

57. Goldkorn T, Mendelsohn J: Transforming growth factor beta modulates phosphorylation of the epidermal growth factor receptor and proliferation of A431 cells. Cell Growth Differ 1992, 3(2):101-109. 
58. Bocchetta M, Eliasz S, De Marco MA, Rudzinski J, Zhang L, Carbone M: The SV40 large $T$ antigen-p53 complexes bind and activate the insulin-like growth factor-I promoter stimulating cell growth. Cancer Res 2008, 68(4):1022-1029.

59. Liu X, Lin CS, Spencer EM, Lue TF: Insulin-like growth factor-I promotes proliferation and migration of cavernous smooth muscle cells. Biochem Biophys Res Commun 2001, 280(5):1307-1315.

60. Kaech S, Covic L, Wyss A, Ballmer-Hofer K: Association of p60c-src with polyoma virus middle-T antigen abrogating mitosis-specific activation. Nature 1991, 350(6317):431-433.

61. Flossmann-Kast BB, Jehle PM, Hoeflich A, Adler G, Lutz MP: Src stimulates insulinlike growth factor I (IGF-I)-dependent cell proliferation by increasing IGF-I receptor number in human pancreatic carcinoma cells. Cancer Res 1998, 58(16):3551-3554.

62. Ichaso N, Dilworth SM: Cell transformation by the middle T-antigen of polyoma virus. Oncogene 2001, 20(54):7908-7916.

63. Bai L, Yang JC, Ok JH, Mack PC, Kung HJ, Evans CP: Simultaneous targeting of Src kinase and receptor tyrosine kinase results in synergistic inhibition of renal cell carcinoma proliferation and migration. Int J Cancer 2012, 130(11):2693-2702.

64. Watanabe G, Howe A, Lee RJ, Albanese C, Shu IW, Karnezis AN, Zon L, Kyriakis J, Rundell K, Pestell RG: Induction of cyclin D1 by simian virus 40 small tumor antigen. Proc Natl Acad Sci U S A 1996, 93(23):12861-12866.

65. Yu Z, Wang C, Wang M, Li Z, Casimiro MC, Liu M, Wu K, Whittle J, Ju X, Hyslop T et al: A cyclin D1/microRNA 17/20 regulatory feedback loop in control of breast cancer cell proliferation. J Cell Biol 2008, 182(3):509-517.

66. Maluquer de Motes C, Smith GL: Vaccinia virus protein A49 activates Wnt signalling by targetting the E3 ligase $\beta$-TrCP. J Gen Virol 2017.

67. Du Y, Zhang S, Yu T, Du G, Zhang H, Yin Z: Wnt3a is critical for endothelial progenitor cell-mediated neural stem cell proliferation and differentiation. Mol Med Rep 2016, 14(3):2473-2482.

68. Stack J, Hurst TP, Flannery SM, Brennan K, Rupp S, Oda S, Khan AR, Bowie AG: Poxviral protein A52 stimulates p38 mitogen-activated protein kinase (MAPK) activation by causing tumor necrosis factor receptor-associated factor 6 (TRAF6) self-association leading to transforming growth factor $\beta$-activated kinase 1 (TAK1) recruitment. J Biol Chem 2013, 288(47):33642-33653.

69. Khiem D, Cyster JG, Schwarz JJ, Black BL: A p38 MAPK-MEF2C pathway regulates B-cell proliferation. Proc Natl Acad Sci U S A 2008, 105(44):17067-17072.

70. Patel AL, Chen X, Wood ST, Stuart ES, Arcaro KF, Molina DP, Petrovic S, Furdui CM, Tsang AW: Activation of epidermal growth factor receptor is required for Chlamydia trachomatis development. BMC Microbiol 2014, 14:277.

71. Chandra A, Lan S, Zhu J, Siclari VA, Qin L: Epidermal growth factor receptor (EGFR) signaling promotes proliferation and survival in osteoprogenitors by increasing early growth response 2 (EGR2) expression. J Biol Chem 2013, 288(28):20488-20498.

72. Prochnau D, Rödel J, Hartmann M, Straube E, Figulla HR: Growth factor production in human endothelial cells after Chlamydia pneumoniae infection. Int J Med Microbiol 2004, 294(1):53-57.

73. Holland EC, Varmus HE: Basic fibroblast growth factor induces cell migration and proliferation after glia-specific gene transfer in mice. Proc Natl Acad Sci U S A 1998, 95(3): 1218-1223.

74. Roxas JL, Koutsouris A, Viswanathan VK: Enteropathogenic Escherichia coli-induced epidermal growth factor receptor activation contributes to physiological alterations in intestinal epithelial cells. Infection and immunity 2007, 75(5):2316-2324. 
75. Poncet N, Guillaume J, Mouchiroud G: Epidermal growth factor receptor transactivation is implicated in IL-6-induced proliferation and ERK1/2 activation in non-transformed prostate epithelial cells. Cell Signal 2011, 23(3):572-578.

76. Franco AT, Israel DA, Washington MK, Krishna U, Fox JG, Rogers AB, Neish AS, Collier-Hyams L, Perez-Perez GI, Hatakeyama M et al: Activation of beta-catenin by carcinogenic Helicobacter pylori. Proc Natl Acad Sci U S A 2005, 102(30):1064610651.

77. Nagy TA, Wroblewski LE, Wang D, Piazuelo MB, Delgado A, Romero-Gallo J, Noto J, Israel DA, Ogden SR, Correa $\mathrm{P}$ et al: $\boldsymbol{\beta}$-Catenin and $\mathbf{p} 120$ mediate PPAR $\delta$-dependent proliferation induced by Helicobacter pylori in human and rodent epithelia. Gastroenterology 2011, 141(2):553-564.

78. Tabassam FH, Graham DY, Yamaoka Y: Helicobacter pylori activate epidermal growth factor receptor- and phosphatidylinositol 3-OH kinase-dependent Akt and glycogen synthase kinase 3beta phosphorylation. Cellular microbiology 2009, 11(1):70-82.

79. Andl CD, Mizushima T, Nakagawa H, Oyama K, Harada H, Chruma K, Herlyn M, Rustgi AK: Epidermal growth factor receptor mediates increased cell proliferation, migration, and aggregation in esophageal keratinocytes in vitro and in vivo. $\mathrm{J} \mathrm{Biol}$ Chem 2003, 278(3):1824-1830.

80. Rodrigues LS, da Silva Maeda E, Moreira ME, Tempone AJ, Lobato LS, RibeiroResende VT, Alves L, Rossle S, Lopes UG, Pessolani MC: Mycobacterium leprae induces insulin-like growth factor and promotes survival of Schwann cells upon serum withdrawal. Cell Microbiol 2010, 12(1):42-54.

81. Ferlin M, Noraz N, Hertogh C, Brochier J, Taylor N, Klein B: Insulin-like growth factor induces the survival and proliferation of myeloma cells through an interleukin-6-independent transduction pathway. Br J Haematol 2000, 111(2):626634.

82. Villaseñor T, Madrid-Paulino E, Maldonado-Bravo R, Urbán-Aragón A, Pérez-Martínez L, Pedraza-Alva G: Activation of the Wnt Pathway by Mycobacterium tuberculosis: A Wnt-Wnt Situation. Front Immunol 2017, 8:50.

83. Fre S, Pallavi SK, Huyghe M, Laé M, Janssen KP, Robine S, Artavanis-Tsakonas S, Louvard D: Notch and Wnt signals cooperatively control cell proliferation and tumorigenesis in the intestine. Proc Natl Acad Sci U S A 2009, 106(15):6309-6314.

84. Toossi Z, Young TG, Averill LE, Hamilton BD, Shiratsuchi H, Ellner JJ: Induction of transforming growth factor beta 1 by purified protein derivative of Mycobacterium tuberculosis. Infection and immunity 1995, 63(1):224-228.

85. Hartsough MT, Mulder KM: Transforming growth factor beta activation of p44mapk in proliferating cultures of epithelial cells. J Biol Chem 1995, 270(13):7117-7124.

86. Quentmeier H, Schmitt E, Kirchhoff H, Grote W, Mühlradt PF: Mycoplasma fermentans-derived high-molecular-weight material induces interleukin-6 release in cultures of murine macrophages and human monocytes. Infection and immunity 1990, 58(5):1273-1280.

87. Roth M, Nauck M, Tamm M, Perruchoud AP, Ziesche R, Block LH: Intracellular interleukin 6 mediates platelet-derived growth factor-induced proliferation of nontransformed cells. Proc Natl Acad Sci U S A 1995, 92(5):1312-1316.

88. Haugwitz U, Bobkiewicz W, Han SR, Beckmann E, Veerachato G, Shaid S, Biehl S, Dersch K, Bhakdi S, Husmann M: Pore-forming Staphylococcus aureus alpha-toxin triggers epidermal growth factor receptor-dependent proliferation. Cell Microbiol 2006, 8(10):1591-1600.

89. Izumi K, Zheng Y, Li Y, Zaengle J, Miyamoto H: Epidermal growth factor induces bladder cancer cell proliferation through activation of the androgen receptor. Int $J$ Oncol 2012, 41(5):1587-1592. 
90. Channon JY, Miselis KA, Minns LA, Dutta C, Kasper LH: Toxoplasma gondii induces granulocyte colony-stimulating factor and granulocyte-macrophage colonystimulating factor secretion by human fibroblasts: implications for neutrophil apoptosis. Infection and immunity 2002, 70(11):6048-6057.

91. Fattorossi A, Battaglia A, Pierelli L, Malinconico P, Andreocci L, Perillo A, Ferrandina G, Martelli O, Rughetti A, Nuti M et al: Effects of granulocyte-colony-stimulating factor and granulocyte/macrophage-colony-stimulating factor administration on $T$ cell proliferation and phagocyte cell-surface molecules during hematopoietic reconstitution after autologous peripheral blood progenitor cell transplantation. Cancer Immunol Immunother 2001, 49(12):641-648. 